\title{
Niyoga,(Levirate) and Sexual Politics in Ancient India; Reflection on the Indian Epic Mahabharata
}

\author{
Dr. Ravi Khangai ${ }^{1}$ \\ Assistant Professor, Department of History \\ Rashtrasant Tukdoji Maharaj Nagpur University \\ Amravati Road, Nagpur, India
}

\begin{abstract}
Indian epic, the Mahabharata is like a reservoir of information about the Indian society. The epic have acquired written form during the period 800B.C. to 200 A.D.1 However before acquiring written form, it was handed down from generation to generation in oral form and had gone through log process of interpolation and extrapolation. During this long process it had acquired eternal relevance and more so for the Indian society, which is considerably rooted in the past. The epic narrates number of episodes where a male child is produced by a woman from a man other than her husband. Apart from the Mahabharata, Manu Smriti also refers to this kind of practice, which was called 'Nìyoga'.This paper will make analysis of some of the episodes of Niyoga narrated in the Mahabharata. The 'Nīyoga' episodes in the Mahabharata were not a simple union of a man and women for procreation (as it was supposed to be), but involves emotions and politics. After all human life is too complicated to be compartmentalized in water tight compartments.

Keywords: Widow, Offspring, Begotten, Lust, Premarital, Heir, Attitude.
\end{abstract}

\section{INTRODUCTION}

Though the social customs goes on changing, the basic human emotions like love, hate and desires remains the same. The Mahabharata captures this interplay of human emotions very effectively. There are many things in the Mahabharata which are quite explicit, but there are many things which can be deciphered by reading between the lines. Iravati Karve writes,

"During the Mahabharata times, the ideal of women's loyalty to her husband differed slightly from that of later times. It was customary then to acquire a son begotten by another man on one's own wife, if one happened not to have an heir. This was called Niyoga............In the Mahabharata times a women was the 'field' and she had to produce children from any man when her husband demanded." (Karve, 2008, P.189)

The prevalence of 'Nīyoga' in Ancient India is also referred by A.L. Basham,

"If the husband was sterile or impotent he had to take further measures. In the last resort he would appoint a close relative, usually a brother, to produce offspring on his behalf. From several stories in the epics and elsewhere it appears that a holy men of special sanctity were also in demand for this purpose...........Similarly if the husband died without producing male issue his brother might act on his behalf. This practice of levirate (Niyoga) was well known in many ancient societies, and references to it are common in early Indian legal literature. Before the beginning of the Christian era, however, it began to be disapproved of, and medieval writers include it among the forbidden Kalivarjya customs, which were permitted in earlier ages.” (Basham, 2004, P. 176)

This type of practice was also followed among the Jews and it was known as 'levirate'. However, in case of levirate, dead husband's brother has to cohabit or marry the widow. In case of 'Niyoga', the brother of the dead husband is preferable but not necessary. Some learned Brahmin can also serve the purpose. This paper examines the different issues involved in the episodes of 'Niyoga' narrated in the Mahabharata.

Patriarchal Indian society is obsessed with son. It is considered that parents will not be emancipated if they do not have son. As a result the society tries to find different ways of obtaining sons in case the natural way of union between husband and wife fails. The Mahabharata (Ganguli, Adi Parva, 2008, Section CXX) refers to the different kind of sons as;

The son begotten by one's self upon his wedded wife.

The son begotten upon one's wife by an accomplished person from motives of kindness

${ }^{1}$ Corresponding Author: ravikhangai@gmail.com 
$>$ The son begotten upon one's wife by a person for pecuniary consideration.

$>$ The son begotten upon the wife after the husband's death

The maiden-born son

The son born of unchaste wife.

The Mahabharata narrates some episodes of children being produced by women from men other than their husband. It does not give systematic information about the procedure of 'Nìyoga'. The circumstances during which 'Nìyoga' can be carried out and the procedure of 'Nĩyoga' is given in the Manu Smriti .

"If the line is about to die out, a wife who is duly appointed may obtain the desired progeny through a brother-in-law or a relative belonging to the same ancestry. The appointed man should smear himself with ghee, approach the widow at night in silence, and beget a single son, never a second............When the purpose of his appointment to the widow has been fulfilled according to rule, however, they should behave towards each other as an elder and a daughter-in-law. If, on the contrary, the appointed couple disregard the rules and behave lustfully with one another, both become outcastes, he is a molester of a daughter-in-law, and she as a violator of an elder's bed." (Olivelle, 2004, p.159)

In the process of 'Nīyoga', a man has to smear himself with ghee, so that he should not look attractive to the woman.

However, the practice is condemned by Manu in the next paragraph itself who says that since the time of Vena2 the practice of acquiring son by widow is done away with,

"Since that time, good people denounce anyone who is senseless enough to appoint a woman to have children after her husband dies" (Olivelle, 2004, p.159)

The dictates of Manu was known to the author/interpolators of the Mahabharata is clear from the episode in Adi Parva. Pānduu tells his wife Kuntī,

"The self-born Manu hath said that men failing to have legitimate offspring of their own may have offspring begotten upon their wives by others" (Ganguli, Adi Parva, 2008,Section CXX)

So the obvious purpose of 'Nīyoga' was to have male offspring and there should not be a lust in the relationship. Manu Smriti does not mention the appointment of Brahmin as a seed giver during 'Nīyoga' but only a brother-inlaw or a relative belonging to the same ancestry.

However the practices of 'Niyoga' that we come across in the Mahabharata do not subscribe to the theoretical description given by Manu. One of the most well known episodes of 'Nīyoga' was the union between sage Vyāsa and the widows of Vicitravīrya; Ambikā and Ambālikā.

\section{VYĀSA'S DESIRE}

King Vicitravīrya of Kuru dynasty ruling over Hāstinapur died without an issue and his two wives Ambikā and Ambālikā became widows. Vicitravīrya's mother, Satyavatī was desirous of having a male offspring on the widows of the Vicitravirya so as to continue the linage of her son. First she approached Bhīshma, the elder half-brother of Vicitravīrya. As Bhīshma was an elder brother of Vicitravīrya, he was suitable for having 'Nìoga' with the widows of Vicitravīrya. However, Bhīshma refused to compromise on his vow of celibacy. He suggested that some Brahmin may be called for 'Nīyoga', Satyavatī revealed that she had a son, who was born to her from sage Parāçara, before her marriage to king Śamtanu and if he can be asked to produce an offspring on the widows of Vicitravīrya? Bhīshma agreed to this and Vyāsa was called. Satyavatī asked Vyāsa to produce a son on Ambikā. Vyāsa says that this practice i.e. producing children on the wives of the dead husband is conformable to the true and eternal religion. He also says that the ladies should observe the rigid vow for one year. What the vow is not described by the Vyāsa. (Ganguli, Adi Parva, 2008, Section CV)

But Satyavatī was in a hurry. She was more worried about the anarchy that may arise in the kingdom in the absence of king. She urges Vyāsa,

"Take such steps that the ladies may conceive immediately. In a kingdom where there is no king, the people perish from want of protection......." (Ganguli, Adi Parva, 2008, Section CV). 
Vyāsa says that in case the act of union is to be performed immediately, the ladies will have to bear his ugliness. He says,

"If I am to give to my brother children so unseasonably, then let the ladies bear my ugliness. That in itself shall, in their case, be the austerest of penances" (Ganguli, Adi Parva, 2008, Section CV)

So theoretically the act of 'Nīyoga' was like a penance for Ambikā. But the penance was also flexible. Vyāsa readily agreed to by pass one year penance and got ready to have 'Nìyoga' immediately.

The main concern of Satyavatī was to have male offspring on her daughter-in-law, so that the kingdom can be saved. But she tells Vyāsa that the widows of Vicitravīrya have become desirous of offspring,

"Thy younger brother hath left two widows like unto the daughters of the celestials themselves, endued with youth and great beauty. For the sake of virtue and religion, they have become desirous of offspring" (Ganguli, Adi Parva, 2008, Section CV)

If it was a union only for producing an heir, why did Satyavatī described the youth and beauty of the widows? Was it to entice Vyāsa? This goes against the process of Niyoga! Secondly she says that 'they' have become desirous of offspring. If Nìyoga was for saving the linage, then Niyoga with one widow would have been enough to begin with. In case it fails then one can think about the second option. But Satyavatī seems to be planning for Nìyoga with two widows since beginning. Neither Bhīshma nor Vyāsa raised any objection to it, indicating that this was not considered objectionable.

Ambikā was convinced to go for union. In fact she was deceived. She was not informed that the person that she is going to have union is a unwashed, smelly sage. However the description indicates that the 'Nìyoga' was celebrated like a ceremony,

"Satyavatī having succeeded with great difficulty in procuring the assent of her virtuous daughter-in-law to her proposal which was not inconsistent with virtue, then fed Brahmanas and Rishis and numberless guests who arrived on the occasion" (Ganguli, Adi Parva, 2008, Section CVI)

The description also gives information that Satyavatī had great difficulty in persuading Ambikā to agree for the union, which contradicts her earlier statement that the widows of Vicitravirya had become desirous of offspring. The episode gives a hint of the cunning politics played by Satyavatī. On the one hand it is narrated in the Mahābhārata, that Satyavatī had to procure the assent of her daughter-in-law with great difficulty. On the other hand she tells Vyāsa that her daughter-in-laws had became desirous of offspring.

Vyāsa enters the bed chamber of Ambikā. Ambikā, who was waiting for some relative of the dead king, suddenly encounters Vyāsa, who was dark-skinned as he is often referred as Krishna -Dvaipāyana. The Mahābhārata says,

"The princess, seeing his dark visage, his matted locks of copper hue, blazing eyes, his grim beard, closed her eye in fear" (Ganguli, Adi Parva, 2008, Section CVI)

The Mahabharata is obviously silent about what happened in the bed-chamber of Ambikā. It only says,

“....the latter, struck with fear, opened not her eyes even once to look at him" (Ganguli, Adi Parva, 2008, Section CVI)

As she did not receive Vyāsa properly, Vyāsa cursed that a child born to her will be blind. There is one more incident narrated in the Mahabharata about punishing the innocent child in the womb by dissatisfied man, the incident of Dīrghatamas, which will come subsequently. If the purpose was procreation only, then why did Vyāsa curse her?

As a blind person cannot become the king, after the birth of Dhrtarastra, Satyavatī asked Vyāsa to go to Ambālikā, the other widowed queen of Vicitrvirya. She also did not felt comfortable and became pale out of fear of Vyāsa, as a result she was also cursed by Vyāsa that her son will be pale. (Ganguli, Adi Parva, 2008, Section CVI)

Satyavatī was not satisfied with the result and desired healthy boy to as a successor to the throne of Hāstinapur. She asked Vyāsa once again to go to Ambikā. This time however, Ambikā played a trick and she sent her maid instead of going herself. The maid received Vyāsa happily and pleased, Vyāsa gave a boon to her that the child born to her will be healthy and wise. (Ganguli, Adi Parva, 2008, Section CVI)

The curses and boon given by Vyāsa goes against the theory of 'Nīyoga'. As per theory the man and woman having 'Nīyoga' should have union only with the intention of producing an offspring. (Olivelle, 2004, p.159) There should 
not be any lust involved. If the feelings are not involved then there is no question of anger and pleasure. Why did Vyāsa became pleased with the maid and granted a boon to her and cursed Ambikā and Ambālikā? Obviously the union with the maid had satisfied Vyāsa and so he granted a boon to her. The union with Ambikā and Ambālikā did not satisfy him and annoyed, he cursed them.

\section{VYĀSA'S LOVE FOR THE MAID}

Vyāsa already had one sexual union with Ambikā, obviously he knew her very well. However when he was called third time and sent to Ambikā again. Ambikā sent her maid instead. As Vyāsa already knew Ambikā, why did he choose to impregnate the maid? As maids were considered as property, the maid of Vicitravīrya's wife Ambikā also belonged to Vicitravīrya. But the purpose of 'Nìyoga' here was to produce an heir to royal throne. The son of a maid could not become the king as is proved later. It was unlikely that Vyāsa, the learned sage did not know about this. Vidura who was born out of union of Vyāsa and the unknown maid was very capable but he was never thought to be suitable to be king on account of his birth. So the whole purpose of 'Niyoga' is defeated in case of the union between Vyāsa and the unknown maid. So the question remains unanswered 'why did Vyāsa do it?'. Probably Vyāsa lusted after her. The Mahabharata describe the beauty of the maid,

“....a maid of hers, endued with the beauty of an Apsarā" (Ganguli, Adi Parva, 2008, Section CVI).

The maid was not only beautiful as Apsarā, but behaved very well towards Vyāsa,

"When the Vyāsa arrived, the maid rose up and saluted him. And she waited upon him respectfully and took her seat near him when asked" (Ganguli, Adi Parva, 2008, Section CVI).

No wonder that it was difficult for Vyāsa to get away even if he wanted to!

Vyāsa was so pleased with her that he freed her from slavery and also granted a boon that a child will be born to her who will be fortunate, virtuous and intelligent.

Ambikā sending her maid instead of herself is also rather intriguing. She already had one union with Vyāsa, so obviously Vyāsa knew her very well. Sending a maid was risky. What if Vyāsa finds out? But by her earlier experience, Ambikā seem to be sure that Vyāsa will not let the chance of having a union with a beautiful maid go! Having united with him once, she was aware of the lusty nature of Vyāsa! The maid also seems to be well trained so as to entice the sage by her behavior.

The whole episode of the 'Nīyoga'of Vyāsa with Ambikā and Ambālikā can be reconstructed. It is not necessary that one union between man and women will result in conception. Manu Smriti recommend repeated union between a widow and her brother in law.

".....he should have sex with her once every time she is in season until she bears a child" (Olivelle, 2004, p.160)

It is likely that Vyāsa stayed in the royal house and cohabited with Ambikā first and with Ambālikā later and during his stay also had relation with the maid.

\subsection{Nīyoga; without Pleasure?}

The Mahabharata tries to bring out the earthly nature of human being in a very subtle way. Sexual behavior is a very complex. Is segregation of sex for procreation and sex for pleasure possible? Vyāsa who had sexual union with Ambikā and Ambālikā and supposed to be composer of the Mahabharata writes,

“..... both Ambikā and Ambālikā were of tall stature, and of complexion of molten gold, and their heads were covered with black curly hair.....their hips were fat and round, and their breast full and deep........" ( Ganguli, Adi Parva, 2008, Section CII)

Sexuality is a part of all living being, but humans are rather hypocrite about it and try to hide it. The authors/interpolators of the Mahabharata makes repeated references to the beauty of Ambikā and Ambālikā. The references to the description of the body of Ambikā and Ambālikā like 'fat and round hips' and 'full and deep breast' have sexual connotations. Presuming Vyāsa is the author of that portion of the Mahabharata, it can be stated that he very closely observed these ladies. If he had narrated the whole of Mahabharata much later, still the memories of the body of the women that he had physical relations with remained in his mind for long. This goes contrary to the theory of the 'Niyoga' which insist on the sex for procreation only, underlining that there should not 
be pleasure involved in it. In fact, the sexual union between a man and women is impossible unless at least the man is sexually aroused. The fact is acknowledged by the Manu Smriti itself,

“.....if the husband is not aroused, there will be no offspring." (Olivelle, 2004, p.48)

It is anticipation of pleasure that led to arousal. Then how a Niyoga can be union without pleasure?

Vyāsa obviously got carried away by anger arising out of denial of pleasure resulting into curse. The Bhagavad Gitā which is part of the Mahabharata says,

"When a man dwells in his mind on the objects of sense, attachment to them is produced. From attachment a spring desire and from desire comes anger.

From anger arises bewilderment, from bewilderment loss of memory; from loss of memory, the destruction of intelligence" (Radhakrishnan, 2004, p.126)

It is due to anger that had arisen as a result of denial of pleasure that Vyāsa forgot that he came here to produce an heir and not for pleasure.

\subsection{Was Vyāsa the Most Suitable Person for Nìyoga?}

As per the 'Niyoga' practice described in Manu Smriti, a relative of husband should perform 'Nīyoga'. Though Bhisshma was not willing to compromise on his vow of celibacy, but was there nobody else related to the family of Vicitravīrya?

The Mahabharata gives information that the King Śamtanu had an elder brother named Vāhlika. In fact, Śamtanu's father king Pratipa had three sons. Devāpi was the eldest, Vāhlika the next and Śamtanu was the youngest. (Ganguli, Udyoga Parva, 2008, Section CXLIX). However Devāpi could not become the king as he was having skin disease. Vāhalika obtained the wealthy kingdom of his maternal grandfather. The Mahābhārata states that it was with the permission of Vāhalika that Śamtanu became the king. Vāhalika's son Somdatta and grandsons Śalya and Bhūriśrava also finds mention in the Mahabharata. Bhūriśrava was a great warrior and was highly respected by Yudhisthira. (Ganguli, Udyoga Parva, 2008, Section XXX) All four of them (Vāhlika, Somdatta, Bhūriśrava and Śalya) fought in the Mahābhārata war on the side of Duryodhana. Vāhlika is mentioned as Atiratha i.e. one of the foremost expert chariot warrior. (Ganguli, Udyoga Parva, 2008, Section CLXVIII )

Vāhlika was Śamtanu's brother, so, Vicitravīrya and Vāhlika's son Somdatta were first cousin and his son Bhūriśrava belonged to the next generation, i.e. generation of Pandu. So if we have to draw the genealogical tree of the house of Pratapi (Śamtanu's father), it will be as follow;

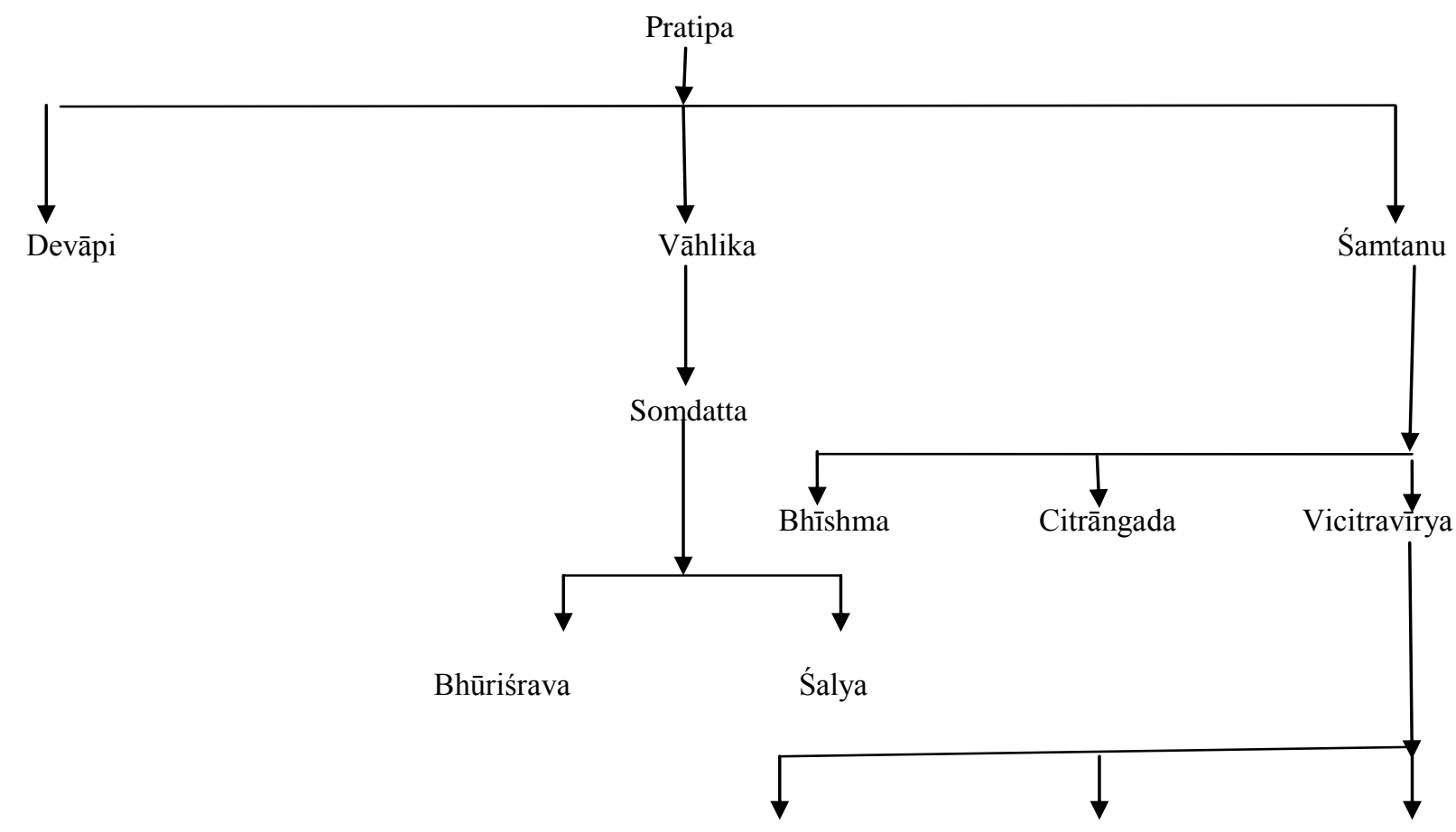




\section{Genological Tree of The Kuru Family from Pratipa to Pandu}

The 'Nīyoga' between Vyāsa and the widows of Vicitravīrya reflects that it was not a simple act of procreation but had some power politics behind it. If Bhīshma had refused to compromise on the vow of celibacy, Somdatta being the cousin of Vicitravirya should have been next choice for 'Nìyoga'. Somdatta, was having two sons indicates that he was not impotent. He also got into deadly conflict with Shīnī for the possession of princess Devakī, during her Svyamvara. (Ganguli, Drona Parva, 2008, Section CXLIII) Vāhlika was killed by Bhīma. Somdatta and his son Bhūriśrava, both were killed by Sātyaki. Arjuna shows great respect for Bhūriśrava.(Ganguli, Drona Parva, 2008, SectionCXLII) This shows that these Kuru princess were respected. Then why Somdatta was not considered to sit on the throne after the death of Vicitravirya? Neither he was called to perform 'Niyoga' on the widows of Vicitravīrya. There could be different reasons behind this.

Văhlika was shown to be present in the Kuru kingdom on number of occasion. He was present at the time of the episode of disrobing of Draupadī3. He along with his son Somdatta and grandsons Śalya and Bhūriśrava were present during the Rājsŭyā Yajňa of Yudhisthira. (Ganguli, Sabha Parva, 2008, XXXIII) Even if Vāhlika and his son Somdatta and grandson Bhūriśrava were staying outside the Kuru kingdom, their presence on number of occasion indicates that they had maintained relations with the Kuru ruling house of Hāstinapur. Even if they were staying away, Somdatta, who was cousin of Vicitravīrya could have been summoned to perform Niyoga on the widows of Vicitravīrya. As Bhīshma had refused, the next logical option would have been Somdatta. The author of the Mahabharata gives an explanation about the refusal of Bhīshma. But it is silent about why Somdatta was not called! Even when first Nìyoga between Vyāsa and Ambikā failed to bring out desired result as the child was blind and not suitable to become king. Still during second attempt of producing heir to the throne, Somdatta was not called. The second 'Nīyoga' was done after the birth of blind Dhrutarāsţra. After the first 'Nīyoga', Vyāsa had already given warning to Satyavatī that the child that will be born will be blind. As the first widow did not receive Vyāsa properly, there was less possibility of other widow receiving him properly, yet Satyavatī was eager to have an heir produced from Vyāsa. Even the result of the second 'Nīyoga' was also not satisfactory. It gave birth to sickly Pandu. Still Satyavatī and Bhīshma did not think about any other alternative. Even though the third attempt also failed to give heir, as the son of a maid could not become the king, still Satyavatī and Bhīshma agreed to make sickly Pandu as the king but did not considered calling Somdatta to perform 'Nīyoga'.

One speculation could be that his age was not suitable. He being the son of Vāhlika, who was the elder brother of Śamtanu, he belonged to the generation of Bhīshma. Bhishma was not described as showing any respect to him throughout the narration of the Mahabharata, so it is likely that he was younger to Bhishma. The children of Satyavatī; Citrāngada and Vicitravīrya, must be quit younger to Bhīshma, as Samtanu married Satyavatī when Bhīshma was a grown up prince. So one can speculate that Somdatta's age must be somewhere in between the age of Bhīshma and Vicitravīrya. As Satyavatī tells Bhīshma to produce sons on the widows of Vicitravīrya, it implies that an elderly person can perform 'Nìoga', so why not Somdatta, who belonged to the Kuru linage as well. Somdatta fighting in the Great War, which took place much after this episode of Niyoga, indicates that he was maintaining good health.

It is likely that Satyavatī and Bhīshma were not willing to let the reins of power go out form their hand. If Somdatta is called, he may claim the throne for himself as being from the linage of the Kuru. If the children are produced from the seed of Somdatta, he may lay claim to the children and his influence in the politics of Hāstinapur will also rise. It was also possible that as Vāhlika is mentioned to have inherited some other kingdom, in future Vāhlika or his son Somdatta will unify the kingdom of Hāstinapur with the kingdom that he had inherited. This was not acceptable to Satyavatī and Bhīshma both. Throughout the infancy of Citrāngada and Vicitravīrya, the kingdom was looked after by Bhīshma. Did he go attach to power and position? The most likely answer is; yes! We see that in the later phase of his life also, he is not willing to let the reins of power go from his hands. When Duryodhana grew up, and the power passes in his hands, Karma becomes his important counselor and we find Bhīshma repeatedly getting into ego clashes with Karma. Probably he was not able to tolerate another power center in the politics of Hāstinapur. So probably he, along with Satyavatī decided to keep Somdatta out from the politics of Hāstinapur and not to let his influence grow. Vyāsa was safe card!

Vyāsa, being a sage was no threat to the position of Bhīshma and Satyavatī. Vyāsa could be satisfied just by some respect and comfort during his periodical visit to Hāstinapur. The arrangement also suited Vyāsa. Being a seed giver to the royal house of Hāstinapur had increased his prestige. In fact he was brought to light by Satyavatī by this 
episode. His oblivion is over. He got one comfortable royal house where he can go and have some refreshing rest, when the austerities of the forest becomes too much to bear! His repeated visit to Hāstinapur and treatment he received at the royal house of the Kuru indicates this. Satyavatī also trusted him as being her own son, he will not turn against her, and he had no political ambition. The 'Niyoga' of rich and famous was a very complicated issue!

\subsection{Whose children?}

The children born out of 'Nīyoga' are considered as children of husband of women weather dead or alive. Women were considered as field and the husband as the owner of the field and the harvest i.e. children are considered as property of the owner of the field.

“......when men without fields sow their seed in someone else's field, they create profits for the owner of the field; the owner of the seed reaps no fruit" (Olivelle, 2004, p.158)

However the Manu Smriti also says that,

"When a field is handed over by contractual agreement to someone for sowing the seed, however, we see in the world that both the owner of the seed and the owner of the field receive shares from it" (Olivelle, 2004, p.158)

The arrangement of the Nīyoga between Vyāsa and the widows of the Vicitravīrya seems to fall in the second category. Vyāsa not only keeps coming in the Mahabharata time and again, but his visit to Hāstinapur is also very frequent. Like a loving grandfather he is also eager to protect his linage. On hearing the birth of the child of Kuntī in the forest, Gāndhāri hit upon her pregnant belly and as a result delivered a ball of flesh. The ball was thrown out, but Vyāsa intervenes. He asks the ball to bring in and dividing it into hundred and one parts preserves them. Out of theses pieces hundred sons and one daughter were born.(Ganguli, Adi Parva, 2008, Section CXV)

Vidura, the son of a maid (whose name is not mentioned) of Ambikā is also regarded as a son of Vicitravīrya, indicating that the body of the maid was also owned by the king. And as the king was her owner, the child born to her, even from other man is considered as a child of the king.

However, it may be mentioned that the child born to the maid was not regarded as a prince. Among the children of Vicitravīrya (born out of Nīyoga), Vidura was probably the most suitable. But he was not considered as suitable to sit on the throne. He was often called as brother by the king Dhrtarastra. He was sometimes given respect and sometimes scolded not only by Dhrtarastra but by Duryodhana as well. This indicates that it is not only the father, but position of mother also determined the position of children in the society.

The authors/interpolators of the Mahabharata, acknowledges Vyāsa as the grandfather of the Pandavas and also says that he begot Pandu, Dhrtarastra and Vidura in order to continue the line of Śamtanu.(Ganguli, Adi Parva, 2008, Section LX). Recognizing the two people as father was probably the accepted norms during those days. One is recognized as a biological father and one on whose name the linage continues. Pandu himself was aware of the fact that Vyāsa was his biological father.(Ganguli, Adi Parva, 2008, Section CXXII)

The Mahabharata says that son born to a maiden as well as son in the womb of a pregnant girl belongs to the man who marries her. (Ganguli, Adi Parva, 2008, Section CXX). According to this, Vyāsa, though born to Satyavatī before her marriage should have been considered as son of Samtanu. Similarly, Karma can be called son of Pandu as Pandu married Kuntī and Karma was born to her before her marriage. But both Satyavatī and Kuntī kept the birth of their pre-marital children secret. Satyavatī kept it secret till the time of the death of her son Vicitravirya and revealed it when the Kuru kingdom was plunged in the crises due to the absence of king. Similarly Kuntī also kept the secret of the birth of Karma and only reveled it to Yudhistira after the death of Karma in the great war. This signifies the changes in the attitude and values in the society towards the sexual morality. Obviously, Satyavatī and Kuntī kept it hidden in due to the fear of being stigmatized or to avoid the hurting of the ego of their respective husband. So there must have been a time when a premarital son was accepted. As the life was uncertain and the wars were frequent, the sons were more important, apart from serving the purpose of ensuring heaven for the parents.

\subsection{Sexual Morality in the Mahabharata}

After the death of Vicitravīrya, when Satyavatī and Bhīshma were discussing about the feasibility of 'Nīyoga', Bhīshma narrated a story of a sage Dìrghatamas. The episode of the birth of Dìrghatamas indicates the practice sexual relation between a women and her brother-in-law (Brother of husband). Bhīshma says,

"There was in olden days a wise Rishi of the name of Utathya. He had a wife of the name of Mamata whom he dearly loved. One day Utathya's younger brother Vrihaspati, the priest of the celestials, endued with great energy, 
approached Mamta. The latter, however told her husband's younger brother.........that she had conceived from her connection with his elder brother and that, therefore, he should not then seek for the consummation of his wishes" (Ganguli, Adi Parva, 2008, Section CIV)

In the narration of this story, Mamata tells Vrihaspati (Brhaspathi) that he should not desire to have physical relation with her because her womb cannot accommodate two children at a time. The child in the womb also addresses Vrihaspati (Brhaspathi) and says,

"O father, cease from thy attempt. There is no space here for two. O illustrious one, the room is small. I have occupied it first. It behoveth thee not to afflict me" (Ganguli, Adi Parva, 2008, Section CIV)

The child in the womb addresses Vrihaspati (Brhaspathi) as father. Though Mamata and the child in her womb tell Brhaspathi to refrain from intercourse with Mamata, the rejection does not say that the act is immoral. The rejection is for the protection of the child in the womb.

Mamata is mentioned as a wife of sage Utathya and not as a combine wife of both the brother. Brhaspathi is mentioned as the priest of celestials. So he is a same Brhaspathi, the priest of the Gods famous through Indian mythology. The story is told by Bhīshma to his step mother Satyavatī. Bhīshma telling this story to Satyavatī is also having certain implications. Bhīshma's character in the Mahabharata is considered as an exemplary from moral standard. Moreover he is narrating the story to his step-mother. The relation between Bhīshma and Satyavatī was always regulated by moderation and mutual respect. It is very unlikely that he will say anything to Satyavatī that goes contrary to morally accepted standard. Celestial Sage Brhaspathi desiring to have sexual relation with the wife of his elder brother, even when his elder brother is alive and his sister-in-law is pregnant, indicates that probably when the Mahabharata was in its initial stage of development, these kind of relations were accepted by the society.

Brhaspathi gets angry at the denial of pleasure of sex and curses the child in the womb,

".....thou hast spoken to me in the way thou hast at a time of pleasure that is sought after by all creatures, perpetual darkness shall overtake thee" (Ganguli, Adi Parva, 2008, Section CIV)

Due to this curse the child was born blind and was called Dīrghatamas (enveloped in perpetual darkness). Later on Vyāsa, dissatisfied with the reception received from Ambikā also curses that the child born to Ambikā will be blind. (Ganguli, Adi Parva, 2008, Section CVI)

It is strange that in both these episodes, the innocent children in the womb are punished for no fault of theirs. The union between Vyāsa and Ambikā also strengthens the notion that mood of the parents at the time of copulation affects the child to be conceived. However, in case of Dïrghatamas, the union between Brhaspathi and Mamata is not mentioned. The child was already conceived from the seed of sage Utathya when Brhaspathi sought union with Mamata.

However the blind child, Dīrghatamas, turned out to be greatly talented. It was he, who angry with the behavior of his wife, later laid down the rule that every woman shall have to adhere to one husband for her life. (Ganguli, Adi Parva, 2008, Section CIV)

However, it was same sage Dīrghatamas who produced eleven children on Shūdra women and also five sons on queen Sudeshnā, the wife of king Vāli, apart from several children on his own wife. (Ganguli, Adi Parva, 2008, Section CIV)

So the rule of adhering to one husband was made by Dīrghatamas for women, but the rule is not applicable to him neither to the women that he had produced children upon. The linage of king Vali continued further by sage Dīrghatamas. The Mahabharata says,

".....it was thus also that mighty bowmen and great car-warriors wedded to virtue, sprung in the Kshatriya race from the seed of Bramanas." (Ganguli, Adi Parva, 2008, Section CIV)

The Mahābhārata gives very varied information about the sexual morality that was practiced at different places and different times. Pandu tells Kuntī,

"Women formally were not immured within houses and dependent on husband and other relatives. They used to go about freely, enjoying themselves as best as they liked........., they did not then adhere to their husbands faithfully, and yet.......they were not regarded sinful, for that was the sanctioned usage of the times. ......the practice is yet regarded with respect among the Nortern Kuru" (Ganguli, Adi Parva, 2008, Section CXXII) 
However this kind of promiscuous relations went out of usage in the course of time and the Mahabharata says it was sage Śvetaketu who laid down the rules regarding the regulation of the man-women relations and made it a rule that a woman should adhere to her husband alone. (Adi Parva, 2008, Section CXXII). Dīrghatamas, as already referred is also mentioned to have laid down the rule for women to adhere to one husband.

The Mahabharata also indicates that the patriarchal society was more worried about the women being conceived from other man's seed than the act of sexual relation itself.

"....a wife when her monthly season cometh4, must ever seek her husband, though at other times she deserveth liberty" (Ganguli, Adi Parva, 2008, Section CXXII)

However a woman was under obligation to raise offspring from another man if commended by her husband.

\subsection{Brahminization of the Mahabharata-}

In the Mahabharata we come across many incidents of Brahamana producing children on other's wives. These are clearly attempts of elevating the status of the Brahmins in the society. The Mahabharata seems to be percolating the idea that the women of other people can also be made available to the Brahman. In the episode of the king Văli and Dīrghatamas, the king was alive when Dīrghatamas produced children on his (king's) wife. There is no mention of king being impotent. (Ganguli, Adi Parva, 2008, Section CIV)

Even at the time of union between sage Parāçara and Satyavatī, the sage soliciting the union says,

"Thou shall remain a virgin even if thou grandest my wish" (Ganguli, Adi Parva, 2008, Section LXIII)

How strange! A sage may have union with a girl, but her virginity will not be lost.

According to the 'Niyoga'(Lavirate) described in 'Manu Smriti' the male who will impregnate the widow has to be 'a brother-in-law or relative belonging to same ancestry' (Olivelle, 2004, p.159). It does not mention that a Brahmin can be appointed for 'Niyoga'. But the Mahabharata repeatedly gives evidences that the Brahmins can be appointed for 'Nīyoga'. When Paraśurāma annihilated the Kstriyas, the Kștriya women were conceived from the Brahmins and their offspring became Kstriyas (Ganguli, Adi Parva, 2008, Section LXIV). Pandu also tells his wife Kuntī that we should call some Brahmins to produce offspring. (Ganguli, Adi Parva, 2008, Section CXX)

This kind of stories helped the Brahmin interpolators of the Mahabharata, to enhance their prestige of the Brahmins in the society. As the writers/ interpolators of the Mahabharata were Brahmins, the idea of Brahminical superiority was systematically propagated through the Mahabharata. Even in 'Niyoga' also it is a Brahmin who is supposed to be called to have union with a woman. Though theoretically it was supposed to be union with the sole desire of producing an offspring, but having sexual relation and not driving pleasure from it is a very difficult aim to achieve, as Vyāsa's boon and curse proves.

There are certain Brahmin communities in India whose surname is 'Niyogi'. The meaning of the Sanskrit word 'Niyogi' means employed. It is quit probable that they are the decedents of those Brahmins who were employed to perform 'Nìyoga'.

\subsection{Who were the Pāndava's Biological Father?}

The Pāndava's were born in the forest, away from the gaze of the people of Hāstinapur. According to the description given in the Mahabharata, Kuntī was given boon by sage Durvāsas. As per this boon she can call any celestial and have offspring through his grace. If Kuntī was given a boon by sage Durvāsas to call upon the God for union, what was the need to go to forest? She could have just summoned a God and had a son from him. In case she wanted to hide the impotency of Pandu, she could have just pretended that those were his sons.

It is likely that Kuntī had children in the forest by union with the different male from the forest dwelling people. The situation that led to the birth of the Pandavas is very complex and threw up many questions.

There was an urgency of child birth, because if Gandhari gives birth to a male child first, that child will be king in future and Gandhari will be mother queen. Women, deprived of independent existence, had no option but to use the position of father, husband and sons to gain respectability in the society. No wonder that she may use any of them as a weapon. Sons are more likely to be used by mothers as she can lay more claim on him as she takes more responsibility in his upbringing.

But if 'Nīyoga' was a accepted practice, then what was the need to hide it? Having 'Nīyoga' in the forest served different purpose. The impotency of Pandu can be hidden from the eyes of the world. There was also better chance 
of mytholizing the birth of the Pandava. As nobody would have became aware that the children are born out of " Nìyoga'. It is most likely that the attitude of society towards 'Nìyoga' had undergone changes. It was now looked down upon. It is also possible that 'Niyoga' with the widows was more acceptable but 'Niyoga' with the wives of impotent husband was not considered as acceptable as this. The obvious reason was that it exposed the impotency of man. The another reason could be that probably Kuntī and Pandu thought that the children born out of 'Nìoga' may not get the support of the people as the children of royal blood i.e. the children of Dhrtarastra will be available. As per Manu Smriti , 'Niyoga' is to be performed if the linage is about to become extinct. That was not the case in Kuru ruling house. If Pandu was impotent, Dhrtarastra can produce children. But if Dhrtarastra 's son becomes king, then what will be the condition of Kuntī? Kuntī wanted her son to succeed to the throne of Hāstinapur and so in a hurry Pandu, Kuntī and Mādrī left for the forest to have 'Nīyoga' with some forest dwelling man.

The primitive instinct displayed by Bhīma, like drinking of blood of Duhśāsana, his fights with the Raksasa also indicates that probably he inherited some wild traits from his forest dwelling biological father, who was mytholised as God 'Vyau', the powerful wind God.

In the case of the birth of the Pandava, it was the king Pandu who convinced Kuntī about the need for child. He says,

"For the childless there is no regions hereafter"(Ganguli, Adi Parva, 2008, Section XCV)

As the epic underwent transformation and expansion, probably the attitude of society towards Niyoga had undergone change. It was now looked down upon. The Pandava's were stigmatized in the epic for that, when Bhīma insults Karma by calling him as 'Son of a charioteer' Duryodhana makes a sarcastic remarks to the Pāndavas and says,

"Your own births ya Pandava princes, are known to me" (Ganguli, Adi Parva, 2008, Section CXXXIX)

To minimize the stigma, the episodes of Nīyoga of Kuntī were mythologized.

\section{CONCLUSION}

The Mahabharata is a very complex epic, reflecting the complexities of human life. The canvas of human life cannot be painted as black and white. It has many gray, intricate shades, which are difficult to express. The Nìyoga episodes analyzed above indicate that dichotomy exist between theory and practice, between what we 'are' and what we 'project'.

The moral values of society go on changing. These changes are reflected in the narration of the Mahabharata. Certain social practices which were accepted norms during certain time went out of use, and we find attempts on the parts of the interpolators of the Mahabharata to camouflage the attempts. We find the narrators of the Mahabharata trying to hide the sexuality of the characters, especially of those who are considered to be respectable, as if respectability and sexuality cannot go together.

Philosophy of withdrawal and renunciation dominates Indian intellectual tradition. We find same attitude dominant in our literature. Denial of desire is considered as virtue and assertion of it as evil.

The women characters like Ambikā and Ambālikā never speaks throughout the narration of the epic. They had no say when they were asked to unite with the smelly sage. Thus the episodes of Niyoga mentioned in the epic treats royal women as objects to be used for producing sons. In contrast the women from the community like Raksasa, Nāgas are portrayed as free in selecting their mate. Raksasi princess Hidimbā ( Ganguly, Adi Parva, 2008, Section CLV) and Naga princess Ulupi (Ganguly, Adi Parva, 2008, Section CCXVI) freely assert their carnal desires. This is not done by any woman characters from the mainstream Brahmin cal society like Kuntī or Draupadī. Thus the patriarchal attitude of the authors/interpolators of the epic is obvious in this two different stereotyping. Probably men wants to have a sexually subdued, coy, homely wife at home, who can be used to produce progenies (specially male) and also wants to have an option open to go out and have tempestuous relation with sexually assertive woman coming from the 'other' section of the society.

The docile women of the mainstream patriarchal society have no control over their bodies is also reflected in the episode when Krishna offers Draupadī to Karma as one of the benefit he may get if he switches side from the Kauravas to the Pandavas. (Ganguli, Udyoga Parva, 2008, Section CXL) 
About Niyoga, the Manu Smriti and the Mahabharata seem to have different perceptions. Former is a book of behavioral code that people were expected to follow and thus present an ideal view about society from the perspective of the law makers. In contrast, the Mahabharata seems to be a reflection of how a society is!

\section{EXPLANATORY NOTES}

The Mahabharata was composed and interpolated with many passages from 800 B.C. to A.D.200.This period is given by Pande G.C. in his essay 'Socio-Cultural Milieu of the Mahabharata: An age of change' in 'Reflections and Variations on the Mahabharata' Sahitya Akademi, New Delhi, 2009. However the period of composition and development of the Mahabharata still remains a contentious issue.

Vena is described as a pre-eminent royal sage, who once ruled entire earth. (Olivelle, p.159)

Vāhlika's presence is mentioned in the Mahabharata published by Gita press, Gorakhpur. The book is in six volume and have Sanskrit verse along with Hindi translation. However this verse is omitted in the English translation of the Mahabharata by K.M. Ganguli. Ganguli in his introduction writes that he used Bengal text and Bombay edition. Gita press edition relay on Nilkanthi and South Indian version of the Mahabharata. Mahabharata have many variations, a successful attempt was made to bring together different versions and prepare a critical edition of the Mahabharata at Bhandarkar Oriental Research Institue, Pune. 1259 manuscripts were consulted and the critical edition was published in 1966. However the Edition is in Sanskrit and so far complete English translation is not available.

Season is mentioned as a time when a woman is likely to be conceived if she has an intercourse.

\section{REFERENCES}

[1] Basham A. L., "The wonder that was India”, Picador, London, 2004.

[2] Ganguli K.M. 'The Mahabharata', Munshiram Manoharlal, New Delhi, 2008.

[3] Karve Irawati, ' Yuganta', Orient Blackswan, Hyderabad, 2008.

[4] Olivelle Patrick, 'The law code of Manu',OUP, New York, 2004.

[5] Radhakrishnan S., "The Bhagavad-Gita” HarperCollins, New Delhi, 2004. 